\title{
Factor V G1691A (Leiden) and prothrombin G20210A gene mutation status, and thrombosis in patients with chronic myeloproliferative disorders
}

Kronik myeloproliferatif hastalık tanilı hastalarda Factor V 1691A (Leiden) ve protrombin G20210A gen mutasyonu ve tromboz

\author{
Nur Soyer ${ }^{1}$, Ali Şahin Küçükarslan², Fahri Şahin ${ }^{1}$, Demet Çekdemir ${ }^{1}$, \\ Buket Kosova ${ }^{2}$, Zuhal Eroğlu ${ }^{2}$, Mahmut Töbü ${ }^{1}$, Murat Tombuloğlu1 ${ }^{1}$, \\ Seçkin Çağırgan ${ }^{1}$, Ayhan Dönmez ${ }^{1}$, Filiz Vural ${ }^{1}$, Güray Saydam ${ }^{1}$ \\ IDepartment of Hematology, Faculty of Medicine, Ege University, Izmir, Turkey \\ ${ }^{2}$ Department of Medical Biology, Faculty of Medicine, Ege University, İmir, Turkey
}

\begin{abstract}
Objective: The aim of this study was to examine Factor V G1691A (Leiden) (FVL) and prothrombin G20210A (PT) gene mutation status, and their relationship with thrombosis in patients with chronic myeloproliferative disorders (CMPDs).

Materials and Methods: The study included 160 patients with a CMPD that were regularly followed-up between 1993 and 2009. FVL and PT mutation status was established based on blood samples analyzed via PCR using specific primers.

Results: The frequency of FVL and PT mutation was $12.5 \%$ and $4.4 \%$, respectively. In total, 27 episodes of thrombosis occurred in $24(15 \%)$ of the patients, and there wasn't an association between the observed thrombotic events, and FVL or PT mutations. Hepatic vein thrombosis was noted in 3 patients that had FVL mutation, of which 1 also had PT mutation.

Conclusion: We did not observe a relationship between thrombosis, and FVL or PT mutations in CMPD patients; however, 3 of the patients that had hepatic vein thrombosis also had FVL mutation. Larger studies are needed to more clearly determine if all CMPD patients with hepatic vein thrombosis need be investigated for FVL and PT mutation. (Turk J Hematol 2011; 28: 306-11)

Key words: Chronic myeloproliferative disorders, factor V Leiden mutation, prothrombin gene mutation, thrombosis

Received: September 20, 2010

Accepted: March 05, 2011

Özet

Amaç: Bu çalışmanın amacı, kronik myeloproliferatif hastalık (KMPH) tanıl hastalarda Factor V G1691A (Leiden) (FVL) ve protrombin (PT) gen mutasyonu durumunu ve bunların trombotik komplikasyonlarla ilişkisini değerlendirmektir.
\end{abstract}

Address for Correspondence: Assoc. Prof. Güray Saydam, Department of Hematology, Faculty of Medicine, Ege University, İzmir, Turkey Phone: +90532556 6128 E-mail: guray.saydam@ege.edu.tr

doi:10.5152/tjh.2011.85 


\begin{abstract}
Yöntemler ve Gereçler: 1993-2009 yılları arasında düzenli olarak takip edilen $160 \mathrm{KMPH}$ hastası çalışmaya alındı. FVL ve PT mutasyon durumunu saptamak için kan örnekleri toplandı ve spesifik primerler kullanılarak PCR ile değerlendirildi.

Bulgular: FVL ve PT mutasyonu sıklı̆̆ı sırasıyla \%12.5 ve \%4.4 olarak bulundu. 24 hastada (\%15) toplam 27 tromboz atağı saptandı ve bu mutasyonlarla tromboz gelişimi arasında herhangi bir ilişki gösterilemedi. FVL mutasyonu olan hastaların 3'ünde hepatik ven trombozu saptandı ve 3 hastanın 1 'inde PT mutasyonu da vardi.

Sonuç: TKMPH'lı hastalarda FVL ve PT mutasyonu ile tromboz arasında herhangi bir ilişki gösterilemedi. Ancak, biz FVL mutasyonu olan hepatik ven trombozlu 3 KMPH hastası saptadı. Hepatik ven trombozlu tüm KMPH hastalarında FVL ve PT mutasyonu bakılmasına gerek olup olmadiğını saptamak için büyük çalışmalara ihtiyaç olduğu gözükmektedir. (Turk J Hematol 2011; 28: 306-11)

Anahtar kelimeler: Kronik myeloproliferatif hastalıklar, Faktör V Leiden mutasyonu, protrombin gen mutasyonu, tromboz
\end{abstract}

Geliş tarihi: 20 Eylül 2010

Kabul tarihi: 05 Mart 2011

\section{Introduction}

Arterial and venous thrombosis are common causes of morbidity and mortality in patients with chronic myeloproliferative disorders (CMPDs). Generally, thrombotic events are more frequently reported than bleeding complications in patients with essential thrombocythemia (ET) and polycythemia vera (PV) at the time of diagnosis and during follow-up [1]. The frequency of thrombotic events in patients with idiopathic myelofibrosis (IMF) was reported to be $7.2 \%-11.6 \%$ [2,3].

Factor V G1691A (Leiden) (FVL) and prothrombin 20210A (PT) gene mutations are the most common genetic anomalies factors in patients with venous thromboembolism. The frequency of FVL ranges from $1.4 \%$ in Italy to $7 \%$ in Greece [4]. In the general Caucasian population the prevalence of the PT 20210A allele is $2 \%$ showing difference according to geographic variation approximately $2 \%$, with some geographic variation [5]. The prevalence of FVL and PT mutation in Turkey was reported to be 7.4\%-10.8\% and $2.6 \%$, respectively [6-10], which differs from the reported incidence of FVL and PT mutation in patients with ET and PV [11-13]. To the best of our knowledge the frequency of FVL and PT mutation in patients with IMF has not been reported. Furthermore, the relationship between thrombophilic factors such as FVL and protrombine mutations thrombophilic factors and the occurrence of thrombosis in patients entering this study these patients remains unclear. As such, the present study aimed to determine the FVL and PT mutation status, and the relationship between these mutations and thrombosis in patients with CMPDs.

\section{Materials and Methods}

The study included 160 CMPD patients that were regularly follow-up at our hematology department between January 1993 and September 2009. Diagnosis of CMPDs was based on the criteria accepted at the time the patients presented (PSVSG ${ }^{14}$ ). All patients were informed about the study and provided written informed consent, and the Ege University Local Ethics Committee approved the study protocol.

Blood samples ( $3 \mathrm{~mL}$ of peripheral blood) were collected into tubes containing EDTA) between February 2008 and September 2009. Patient data were collected at the time of sample collection based on the patient files, and included date of diagnosis, occurrence of arterial and venous thrombosis, symptoms, and complete blood count and other laboratory measurements at the time of diagnosis.

We used the blood samples to identify FVL G1691A and PT 20210A gene mutations. Genomic DNA was extracted from peripheral leukocytes using the High Pure PCR Template Preparation Kit (Roche Applied Science). In brief, $200 \mu \mathrm{L}$ of DNA binding buffer ( $6 \mathrm{M}$ guanidine- $\mathrm{HCl}, 10 \mathrm{mM}$ urea, 10 $\mathrm{mM}$ Tris- $\mathrm{HCl}$, and $20 \%$ Triton $\mathrm{X}-100$ [pH 4.4]) and 40 $\mu \mathrm{L}$ of proteinase $\mathrm{K}$ were added to $200 \mu \mathrm{L}$ of EDTAcontaining blood. The mixture containing proteinase $\mathrm{K}$ was incubated for $10 \mathrm{~min}$ at $72^{\circ} \mathrm{C}$, and then $100 \mu \mathrm{L}$ of isopropanol was added to the mixture samples, which were placed in filter tubes containing glass fiber (in order to bind DNA) and centrifuged at $8000 \mathrm{rpm}$. The DNA that bound to the filter tubes was washed twice with buffer $(20 \mathrm{mM} \mathrm{NaCl}$ 
and $2 \mathrm{mM}$ Tris-HCl [pH 7.5]). Warm elution buffer (10 mM Tris [pH 8.5]) was then added to the DNAbound filter tubes, which were then centrifuged at $8000 \mathrm{rpm}$ to collect DNA. DNA solutions obtained with this procedure were directly available for FVL and PT mutation analysis, which was performed according to the manufacturer's instructions.

The presence of FVL G1691A and PT G20210A mutation was analyzed using commercially available Light Cycler FVL and PT mutation detection kits (Roche Applied Science). Wild type and mutated alleles were identified using the specific melting temperature (Tm) of the resulting amplicons. Tm values for FVL were $65^{\circ} \mathrm{C}$ for the wild type allele and $57^{\circ} \mathrm{C}$ for the $\mathrm{G} 1691 \mathrm{~A}$ allele, and for PT $60^{\circ} \mathrm{C}$ for the wild type allele and $49^{\circ} \mathrm{C}$ for the G20210A allele.

\section{Statistical analysis}

Statistical analysis of the data was performed with using SPSS v.12.0 for Windows (SPSS Inc, Chicago, III). Fisher's exact test was used to determine the significance of the difference between categorical variables (arterial and venous thrombosis, FVL and PT mutation, diagnostic subgroups). P values $<0.05$ were accepted as statistically significant.

\section{Results}

Among the 160 CMPD patients, 88 (55\%) had ET, 48 (30\%) had PV, 15 (9.3\%) had IMF, and 9 (5.7\%) had an unclassified CMPD. Median age of the patients (88 males and 77 females) was 59 years (range: 21-88 years). Patient characteristics are presented in Table 1.
As at the time of presentation the patients' symptoms were quite varied, symptoms were classified based on systems. The patients' symptoms are shown in Table 2.

In total, 27 episodes of thrombosis occurred in 24 (15\%) of the 160 patients, and included 12 arterial and 15 venous episodes. Hepatic vein thrombosis was noted in 3 patients with FVL mutation, of which and 1 also had PT mutation. In all, 7 patients had portal vein thrombosis, none of which had FVL or PT mutation. The frequency of arterial and venous thrombotic events did not differ between patient diagnostic subgroups ( $p>0.05)$. Whereas 16 (18.2\%) thrombotic events were documented in 88 patients with ET, 7 (14.5\%) thrombotic events were recorded in 48 patients with PV. In all, 2 thrombotic events (13.3\%) occurred in 1 of the 15 patients with IMF, which were not associated with any thrombophilic factors. FVL and PT gene mutations were noted in $20(12.5 \%)$ and $7(4.4 \%)$ of the 160 CMPD patients,

Table 2. Frequency of Symptoms

\begin{tabular}{lcc}
\hline Symptoms & n & \% \\
\hline Thrombocytosis based on routine CBC & 64 & 40 \\
Neurologic symptoms & 24 & 15 \\
Polycythemia based on routine CBC & 18 & 11.3 \\
Gastrointestinal symptoms & 16 & 10 \\
\hline Hematologic symptoms & 9 & 5.6 \\
Systemic symptoms & 8 & 5 \\
Others & 8 & 5 \\
Ruddy cyanosis & 5 & 3.1 \\
Cardiovascular and pulmonary symptoms & 3 & 1.9 \\
Pruritus & 3 & 1.9 \\
Visual symptoms & 2 & 1.2
\end{tabular}

Table 1. Patient Characteristics

\begin{tabular}{|c|c|c|c|c|c|}
\hline Characteristics & Total & ET & PV & IMF & Unclassified CMPD \\
\hline$n$ & 160 & 88 & 48 & 15 & 9 \\
\hline Age (years) & $59(21-88)^{*}$ & $57(21-88)^{*}$ & $59.5(24-82) *$ & $60(32-80)^{*}$ & $62(36-75)^{*}$ \\
\hline Female & 77 & 39 & 19 & 6 & 3 \\
\hline Months since diagnosis & $31.5(5-282) *$ & $27(5-160)^{*}$ & $42.5(5-282) *$ & $25(5-147)^{*}$ & $24(15-136)^{*}$ \\
\hline White blood cell count $\left(\times 10^{9} / \mathrm{L}\right)$ & $11.4(3.15-73)^{*}$ & $10.2(4.87-35)^{*}$ & $13(7.13-40.2)^{*}$ & $13.2(3.15-73)^{*}$ & $14.8(4.82-44.4)^{*}$ \\
\hline $\operatorname{ESR}(\mathrm{mm} / \mathrm{h})$ & $6(2-61)^{*}$ & $9(2-61)^{*}$ & $5.5(2-22)^{*}$ & $16(2-46)^{*}$ & $2.5(2-7)^{*}$ \\
\hline LDH (/UL) & $419(131-2841)^{*}$ & $400(131-991)^{*}$ & $407.5(134-2201) *$ & $1026(638-2841)^{*}$ & $440(244-1180)^{*}$ \\
\hline
\end{tabular}

*Median (range) 
respectively. All the observed mutations were heterozygous (Table 3 ). In total, 5 (21\%) of the 24 patients with thrombosis had FVL mutation, of which 1 also had PT gene mutation. There wasn't an association between thrombosis, and FVL or PT mutation carriership ( $p>0.05)$.

The clinical characteristics of the patients (age, erythrocyte sedimentation rate [ESR], leukocyte count, hematocrit, platelet count, and lactate dehydrogenize $[\mathrm{LDH}]$ ) with and without FVL mutation did not differ ( $p>0.05)$, nor did those of the patients with and without PT gene mutation $(p>0.05)$. Arterial and venous thrombotic events were not associated with the presence of FVL or PT gene mutation ( $p>0.05)$.

\section{Discussion}

Thrombotic events during the clinical course of CMPDs cause morbidity and mortality. Prevention of these events is among the primary goals of the treatment of CMPDs. In addition, hereditary thrombophilic factors are the most important cause of venous thrombosis. It remains unclear if there is a relationship between these factors and thrombotic events in CMPD. The present study examined the frequency of FVL and PT mutation in CMPD patients, as well as the relationship between FVL and PT mutation, and arterial and venous thrombotic events.

The frequency of thrombotic events in the patients with ET and PV (18.2\% and 14.5\%, respectively) was similar to that previously reported (11\%$29.4 \%$ and $13 \%-38.6 \%$, respectively) [1,15]. In all, 2 (13.3\%) thrombotic events occurred in 1 of the 15 patients with IMF in the present study. A retrospective study reported that 11 of 26 patients with IMF had arterial or venous thrombosis [13,14,16]. Cervantes et al. reported that 31 (20\%) thrombotic events occurred in 18 of 155 IMF patients [2]. Barbui et al. assessed the frequency of major cardiovascular events in 707 patients with IMF; fatal and nonfatal thrombosis occurred in 51 (7.2\%) of the patients [3], although among the IMF patients in the present study the rate was (6.6\%) slightly lower. It was reported that arterial events are very common at the time of diagnosis in PV and ET patients, but we observed similar frequencies of arterial and venous events in ET (8\% and 10.2\%) and PV (8.3\% and $6.2 \%)$ patients [17-20].

In the present study the frequency of FVL mutation was $12.5 \%$, which is (7.4\%-10.8) slightly higher than previously reported $[6,7,10]$. The frequency of PT mutation was $4.4 \%$ in the present study-2-fold greater than in the general population $[5,8,9]$. While the frequency of these mutations in the present study was higher than previously reported, a relationship between thrombosis, and these mutations in patients with ET, PV, and IMF was not observed. A large retrospective study reported that the frequency of FVL mutation in PV and ET patients was similar to that in the general population and that the mutation was strongly associated with venous thrombotic events prior to and at the time of diagnosis and relapse [11]. Another study reported that there was an increase in the risk of thromboembolic events in patients with ET and PV due to PT mutation [21]. In contrast, some studies reported that there wasn't a significant association between thrombosis and hereditary thrombophilic factors in CMPD patients [12,13]. Although leukocytosis is a risk factor for thrombosis in patients with PV and ET $[19,20,22,23]$, the role of hereditary thrombophilic factors for etiology of thrombosis in those disorders remains unclear.

All patients in the present study with hepatic vein thrombosis had FVL mutation carriership, of which 1 also had PT mutation; however, none of patients with portal vein thrombosis had a thrombophilic mutation. FVL and PT mutations were observed in

Table 3. Frequency of Thrombotic Events and Gene Mutations

\begin{tabular}{|c|c|c|c|c|c|}
\hline & $\begin{array}{c}\text { Factor V } \\
\text { Leiden }\end{array}$ & $\begin{array}{c}\text { Prothrombin } \\
\text { 20210A }\end{array}$ & $\begin{array}{c}\text { Total } \\
\text { thrombotic } \\
\text { events }\end{array}$ & $\begin{array}{c}\text { Venous } \\
\text { thrombotic } \\
\text { events }\end{array}$ & $\begin{array}{c}\text { Arterial } \\
\text { thrombotic } \\
\text { events }\end{array}$ \\
\hline CMPD Patients $(n=160)$ & $20(12.5 \%)$ & $7(4.4 \%)$ & $27(16.9 \%)$ & $15(9.4 \%)$ & $12(7.5 \%)$ \\
\hline$P V(n=48)$ & $4(8.3 \%)$ & $3(6.25 \%)$ & $7(14.5 \%)$ & $3(6.25 \%)$ & $4(8.3 \%)$ \\
\hline $\operatorname{IMF}(n=15)$ & $2(13.3 \%)$ & $1(6.6 \%)$ & $2(13.3 \%)$ & $2(13.3 \%)$ & $0(0 \%)$ \\
\hline
\end{tabular}


25.6\%-26.4\% and 0\%-4.7\% of patients with Budd Chiari syndrome, and in $6.06 \%-7.6 \%$ and $0 \%-3.2 \%$ of patients with portal vein thrombosis, respectively [24,25]. Furthermore, the prevalence of a latent CMPD in patients with hepatic or portal vein thrombosis was estimated to range between $40 \%$ and $60 \%$ [26,27].

In conclusion, even though there wasn't a relationship between thrombosis, and FVL or PT mutation in the present study's patients with ET, PV, and PMF, 3 CMPD patients with hepatic vein thrombosis had FVL mutation. Additional large-scale studies are needed to more clearly determine if all CMPD patients with hepatic vein thrombosis should be investigated for FVL and PT mutation.

\section{Conflict of interest statement}

The authors of this paper have no conflicts of interest, including specific financial interests, relationships, and/or affiliations relevant to the subject matter or materials included.

\section{References}

1. Elliott MA, Tefferi A. Thrombosis and haemorrhage in polycythaemia vera and essential thrombocythaemia. Br J Haematol 2005;128:275-90. [CrossRef]

2. Cervantes F, Alvarez-Larrán A, Arellano-Rodrigo E, Granell M, Domingo A, Montserrat E. Frequency and risk factors for thrombosis in idiopathic myelofibrosis: analysis in a series of 155 patients from a single institution. Leukemia 2006;20:55-60. [CrossRef]

3. Barbui T, Carobbio A, Cervantes F, Vannucchi AM, Guglielmelli P, Antonioli E, Alvarez-Larrán A, Rambaldi A, Finazzi G, Barosi G. Thrombosis in primary myelofibrosis: incidence and risk factors. Blood 2010;115:778-82. [CrossRef]

4. Bauduer F, Lacombe D. Factor V Leiden, prothrombin 20210A, methylenetetrahydrofolate reductase $677 \mathrm{~T}$, and population genetics. Mol Genet Metab 2005;86:91-9. [CrossRef]

5. Vicente V, González-Conejero R, Rivera J, Corral J. The prothrombin gene variant $20210 \mathrm{~A}$ in venous and arterial thromboembolism. Haematologica 1999;84:356-62.

6. Gurgey A, Mesci L, Renda Y, Olcay L, Kocak N, Erdem G. Factor V Q 506 mutation in children with thrombosis. Am J Hematol 1996;53:37-9. [CrossRef]

7. Akar N, Akar E, Dalgin G, Sözüöz A, Omürlü K, Cin S. Frequency of Factor V (1691 G --> A) mutation in Turkish population. Thromb Haemost 1997;78:1527-8.

8. Akar N, Misirlioglu M, Akar E, Avcu F, Yalçin A, Sözüöz A. Prothrombin gene 20210 G-A mutation in the Turkish population. Am J Hematol 1998;58:249. [CrossRef]

9. Gürgey A, Hicsönmez G, Parlak H, Balta G, Celiker A.
Prothrombin gene 20210 G-A mutation in Turkish patients with thrombosis. Am J Hematol 1998;59:79-80.

10. Akar N. Factor V 1691 G-A mutation distribution in a healthy Turkish population. Turk J Hematol 2009;26:9-11.

11. Ruggeri $\mathrm{M}$, Gisslinger $\mathrm{H}$, Tosetto A, Rintelen C, Mannhalter C, Pabinger I, Heis N, Castaman G, Missiaglia E, Lechner K, Rodeghiero F. Factor V Leiden mutation carriership and venous thromboembolism in polycythemia vera and essential thrombocythemia. Am J Hematol 2002;71:1-6. [CrossRef]

12. Afshar-Kharghan V, López JA, Gray LA, Padilla A, Borthakur G, Roberts SC, Pruthi RK, Tefferi A. Hemostatic gene polymorphisms and the prevalence of thrombotic complications in polycythemia vera and essential thrombocythemia. Blood Coagul Fibrinolysis 2004;15:21-4. [CrossRef]

13. Amitrano L, Guardascione MA, Ames PR, Margaglione M, Antinolfi I, Iannaccone L, Annunziata M, Ferrara F, Brancaccio V, Balzano A. Thrombophilic genotypes, natural anticoagulants, and plasma homocysteine in myeloproliferative disorders: relationship with splanchnic vein thrombosis and arterial disease. Am J Hematol 2003;72:75-81. [CrossRef]

14. Murphy S. Diagnostic criteria and prognosis in polycythemia vera and essential thrombocythemia. Semin Hematol 1999;36:9-13.

15. Landolfi R, Di Gennaro L, Falanga A. Thrombosis in myeloproliferative disorders: pathogenetic facts and speculation. Leukemia 2008;22:2020-8. [CrossRef]

16. Marchioli R, Finazzi G, Landolfi R, Kutti J, Gisslinger H, Patrono C, Marilus R, Villegas A, Tognoni G, Barbui T. Vascular and neoplastic risk in a large cohort of patients with polycythemia vera. J Clin Oncol 2005;23:2224-32. [CrossRef]

17. Gangat N, Strand J, Li CY, Wu W, Pardanani A, Tefferi A. Leucocytosis in polycythaemia vera predicts both inferior survival and leukaemic transformation. $\mathrm{Br} \mathrm{J}$ Haematol 2007;138:354-8. [CrossRef]

18. Campbell PJ, Scott LM, Buck G, Wheatley K, East CL, Marsden JT, Duffy A, Boyd EM, Bench AJ, Scott MA, Vassiliou GS, Milligan DW, Smith SR, Erber WN, Bareford D, Wilkins BS, Reilly JT, Harrison CN, Green AR; United Kingdom Myeloproliferative Disorders Study Group; Medical Research Council Adult Leukaemia Working Party; Australasian Leukaemia and Lymphoma Group. Definition of subtypes of essential thrombocythaemia and relation to polycythaemia vera based on JAK2 V617F mutation status: a prospective study. Lancet 2005; 366:1945-53. [CrossRef]

19. Carobbio A, Finazzi G, Guerini V, Spinelli O, Delaini F, Marchioli R, Borrelli G, Rambaldi A, Barbui T. Leukocytosis is a risk factor for thrombosis in essential thrombocythemia: interaction with treatment, standard risk factors and Jak2 mutation status. Blood 2007;109:2310-3. [CrossRef]

20. Landolfi R, Di Gennaro L, Barbui T, De Stefano V, Finazzi G, Marfisi R, Tognoni G, Marchioli R; European Collaboration on Low-Dose Aspirin in Polycythemia Vera (ECLAP). Leukocytosis as a major thrombotic risk 
factor in patients with polycythemia vera. Blood 2007;109:2446-52. [CrossRef]

21. Gisslinger H, Müllner M, Pabinger I, Heis-Vahidi-Fard N, Gisslinger B, Brichta A, Bachleitner-Hofmann T, Mannhalter C. Mutation of the prothrombin gene and thrombotic events in patients with polycythemia vera or essential thrombocythemia: a cohort study. Haematologica 2005;90:408-10.

22. Carobbio A, Antonioli E, Guglielmelli P, Vannucchi AM, Delaini F, Guerini V, Finazzi G, Rambaldi A, Barbui T. Leukocytosis and risk stratification assessment in essential thrombocythemia. J Clin Oncol 2008;26:2732-6. [CrossRef]

23. Wolanskyj AP, Schwager SM, McClure RF, Larson DR, Tefferi A. Essential thrombocythemia beyond the first decade: life expectancy, long-term complication rates, and prognostic factors. Mayo Clin Proc 2006;81:159-66. [CrossRef]

24. Mohanty D, Shetty S, Ghosh K, Pawar A, Abraham P. Hereditary thrombophilia as a cause of Budd-Chiari syndrome: a study from Western India. Hepatology 2001;34:666-70. [CrossRef]

25. Janssen HL, Meinardi JR, Vleggaar FP, van Uum SH, Haagsma EB, van Der Meer FJ, van Hattum J, Chamuleau RA, Adang RP, Vandenbroucke JP, van Hoek B, Rosendaal FR. Factor V Leiden mutation, prothrombin gene mutation and deficiencies in coagulation inhibitors associated with Budd-Chiari syndrome and portal vein thrombosis: results of a case-control study. Blood 2000;96:2364-8.

26. Chait Y, Condat B, Cazals-Hatem D, Rufat P, Atmani S, Chaoui D, Guilmin F, Kiladjian JJ, Plessier A, Denninger $\mathrm{MH}$, Casadevall N, Valla D, Brière JB. Relevance of the criteria commonly used to diagnose myeloproliferative disorder in patients with splanchnic thrombosis. Br J Haematol 2005;129:553-60. [CrossRef]

27. Briere JB. Budd-Chiari Sindrome and Portal Vein Thrombosis associated with myeloproliferative disorders: diagnosis and management. Semin Thromb Haemost 2006;32:208-18. [CrossRef] 